University of New Hampshire

University of New Hampshire Scholars' Repository

$12-2014$

\title{
Generational Inversions: 'Working' for Social Reproduction amid HIV in Swaziland
}

\author{
Casey Golomski \\ University of New Hampshire, Durham, casey.golomski@unh.edu
}

Follow this and additional works at: https://scholars.unh.edu/anth_facpub

Part of the African Languages and Societies Commons, Christianity Commons, Community Health and Preventive Medicine Commons, Missions and World Christianity Commons, and the Social and Cultural Anthropology Commons

\section{Comments}

This is an Author's Original Manuscript of an article published by Taylor \& Francis in African Journal of AIDS Research in 2014, available online: https://dx.doi.org/10.2989/16085906.2014.961942

\section{Recommended Citation}

Golomski, Casey, "Generational Inversions: 'Working' for Social Reproduction amid HIV in Swaziland" (2014). African Journal of AIDS Research. 15.

https://scholars.unh.edu/anth_facpub/15

This Article is brought to you for free and open access by the Anthropology at University of New Hampshire Scholars' Repository. It has been accepted for inclusion in Anthropology Scholarship by an authorized administrator of University of New Hampshire Scholars' Repository. For more information, please contact

Scholarly.Communication@unh.edu. 


\title{
Author \\ Casey Golomski
}

\begin{abstract}
page
Title: Generational inversions: 'working' for social reproduction amid HIV in Swaziland

Abstract: How do people envision social reproduction when regular modes of generational succession and continuity are disrupted in the context of HIVIAIDS? How and where can scholars identify local ideas for restoring intergenerational practices of obligation and dependency that produce mutuality rather than conflict across age groups? Expanding from studies of HIVIAIDS and religion in Africa, this article pushes for an analytic engagement with ritual as a space and mode of action to both situate local concerns about and practices for restoring dynamics of social reproduction. It describes how the enduring HIVIAIDS epidemic in Swaziland contoured age patterns of mortality where persons identified socially and chronologically as youth have predeceased their elders. Based on discourse analyses of ethnography at church worship services and life cycle rites between 2008 and 2011, I show how both elders and youth understood this crisis of "generational inversions" as a non-alignment of age groups and articulated projects to restore succession and continuity in vernacular idioms of 'work' as moralized social and ritual action.
\end{abstract}

Keywords: intergenerational relations, ritual, mutuality, Christianity, mortality, anthropology, discourse analysis, Swaziland 


\section{Body of text and full references}

\section{Introduction}

In July 2011 on warm Sunday morning in the Swazi countryside, a man spoke at the funeral for his brother-in-law, 'It is a curse to wear mourning gowns for your children.' The deceased was a 35-year old migrant labourer to South Africa. The speaker addressed the older attendees, noting that his sister, the young first wife of the deceased, would remain deferential to them as an in-law and get help from her children in keeping up the marital home. Turning to his nieces and nephews he commanded, 'Abide by your elders, who are your mother's in-laws, and look after this home.'

This ethnographic token from a funeral cites manifold complications for normative ideals about intergenerational relations and the ways that families and communities might work through the continuing crisis of HIVIAIDS and its associated mortality, similar to many other places across Africa and globally. The problem of generations in this particular context is acute given age patterns of mortality in this population where youth in the local socio-cultural and categorical sense by and large predecease their elders. These conditions pose several problems-policy-programmatic, economic, social, and religious-existential—for thinking about the dynamics of social reproduction broadly.

Indeed, a motivating research problem and question of this article surround the representations and perceptions of this 'curse.' If a person dies in their late 20s or early 30 s, at the cusp of social adulthood in this cultural context, what does this mean for those who are already alive and older and those yet to be born? What happens to normative ideas of care and obligation that link or run across generational axes? Broadly, how do members of a society make sense of this situation, and where can scholars identify local ideas to restore social reproduction? Returning to this particular funeral and related forums in Swaziland, this article considers this "where" question by focusing on religious ritual as a space and modality for local articulation of concerns about intergenerational relations and social reproduction amid HIVIAIDS. 
Importantly, scholars have questioned the changing dynamics of intergenerational relations amid HIVIAIDS in Southern Africa (Chazan 2008, Gwebu 2008, Gibbs, Campbell, Maimane, Nair 2010, Schatz, Gilbert \& McDonald 2013, Swartz 2013). Concern has centered on how the "intergenerational bargain is becoming progressively harder to maintain" (Barnett and Whiteside 2002, 221), or how social reproduction can be maintained institutionally and in families when people are incapacitated by disease, violence, and limited economic opportunities. A greater proportion of this work focuses on the burdens grandmothers and extended families face when taking on care-giving responsibilities for orphaned and vulnerable children (OVC) after able-bodied adult parents to these children die or are disabled due to illness. Ethnographies on youth, families, and intergenerational relations in Africa are substantial (Ingstad 2004, Honwana \& deBoeck 2005, Christiansen, Utas \& Vigh 2006, Alber, van der Geest, \& Reynolds White 2008, Cole 2010), and several scholars note that HIVIAIDS in this context incites a "crisis" of social reproduction (Prince 2006, Dahl 2009, Hunter 2010, Smith \& Mbakwem 2010). Similarly in these analyses, economic deprivation compounds the effects of HIVIAIDS to disrupt kinship and families. Given its sexual mode of transmission, HIV portends a risky reproduction of kinship. While marriage works to establish idealized intergenerational and affinal ties, in impoverished and HIV prevalent settings these kinship ideals are rendered ambiguous or contingent as people engage in multiple concurrent partnerships due to migratory labour or delay gift and labor exchanges which would otherwise solidify families and care-giving obligations (Cole \& Durham 2007, Hirsch, Wardlow, Smith, Phinney, Parikh, Nathanson 2010).

It is an interesting project to collocate ethnographies of generations in Africa, amid HIVIAIDS or otherwise, with the literature on HIVIAIDS and religion in Africa (Pfeiffer 2005, Becker \& Geissler 2007, Prince, Denis \& van Dijk 2009, Dilger, Burchardt \& van Dijk 2010, Dilger \& Luig 2010, Klaits 2010, Burchardt, Patterson \& Rasmussen 2013, Beckmann, Gusman \& Shroff 2014). This scholarship has widely detailed: how religious practices and beliefs provide local frames of explanation for understanding HIV illness experience and how practices and beliefs have also been reshaped; and how churches, 
mosques, and new religious movements' engage their respective communities as well as local, statist and global health research and development organizations surrounding issues of HIV. Interpersonal and inter-organisational religious dialogue, across regions and nations, has engendered new health-centered subjectivities, networks of activism, and perceptions and uptake of biomedical regimens.

In this expansive literature, attention to changing social formations of kinship, gender, and community have been crucial, including a few with explicit focus on intergenerational relations. Here, intergenerational relations are often conceptualized by more standard Africanist social science analyses as conflict surrounding gerontocratic authority or youth rebellion, where youth and elders clash (Wilson 1977, Aguilar 1998, Carton 2000). For example, Christian youth in Uganda place themselves in moral contradistinction to elders in fighting against AIDS (Gusman 2009) whereas Beckmann (2009) finds that elders criticize youth in Zanzibar mosques (see also Svensson 2009, Quaranta 2010). Fewer works show instances of intergenerational relations forged through practices and discourses of mutuality, namely exchanging sentiments and ideas that affect how multiple groups positively perceive and act towards each other. This article aims to show how religious ritual enables articulations of intergenerational mutuality and re-alignment (see also Durham \& Klaits 2002, Reis 2008). Traditionalist rituals of burial, mourning and widow inheritance were earlier foci of study (Dilger 2006, Prince 2007, Haram 2010), but worship services and religious spaces have otherwise not been strongly conceptualized as ritual proper nor through an intergenerational or life course perspective.

Religious ritual action gives people extra-ordinary license to make ethical and truth claims about social relations and illness experience. Ritual practitioners are not unreflexive that what they do is a ritual or performance. Yet practitioners come to revalue those actions in ritual context as extra-ordinarily significant and different from the same actions done in non-ritual contexts, as well as perceive those actions to be authored not by themselves but divinity (Humphrey and Laidlaw 1994). As Houseman (2006, p. 246) notes, "ritual appears as a distinctive mode of cultural transmission 
geared to the organisation of action: it facilitates the ongoing relevance of certain cultural values and ideas by packaging them in the form of highly memorable relational enactments the experience of which provides participants with self-referential contexts in whose light these values and ideas may be justifiably put into effect."

With regard to social relations of generation, ritual socializes youth, shores up elders' prowess as arbiters of cultural knowledge, remakes gendered personhood across the life course, and legitimates exchange relationships. Ensconced in religious ideology, ritual enacts normative, ethical frameworks for obligations across generations and informs ideas about relatedness and public life. In a social landscape where funerals are or have become major public spaces to make claims about relatedness and mutuality (Durham \& Klaits 2002, Jindra \& Noret 2013) it behooves researchers to describe how religious ritual space and modes of action show the multiple ways in which people identify and interpret social change, as well as seek solutions across agerelated differences. Ritual reinforces status hierarchies across such differences but also provides license for claims of independence and inclusion (Bloch 2006), and these functions should not be held as mutually exclusive. Indeed, writing about contemporary economic precarity in Southern Africa, Ferguson (2013) suggests that power, hierarchy, and dependency are historically situated values and the grounds to realize objectives for social reproduction amid uncertainty. Similarly, I show how for many Swazis, restoring intergenerational relations is more a religious ritual project of mutuality, rather than one laced with antagonism or conflict, where both youth and elders make cooperative claims for a particular future based on shared values they feel beholden to.

Swaziland's HIV/TB/poverty syndemic and its age patterns of mortality inflect religious ritual ideas and practices about intergenerational relations. I characterize this permeation of structural processes and lived experiences of age and life course (Lynch \& Danely 2013), in this case where youth predecease elders, as 'generational inversions,' meaning conventional logics and practices of aging, intergenerational obligation, and aligned succession of cohorts are inverted or disrupted. I describe several vernacular means that many Swazis use to talk about and act on this inversion 
to restore succession and continuity. First, I describe how in these rituals youth and elders talked about 'work' as a mode of social and religious action that would properly re-align the two generations. Second, it was said that work to align generations was supposed to be enacted through practices of mutual respect or deference. Finally, statements about a sufferable social world and the prospects for its restoration in the context of a ritual were made analogous to critical commentary on mistakes of the ritual procedure in situ and how to do the ritual correctly. In other words, ideas about a compromised social world due to death and HIVIAIDS were paralleled with ideas that the ritual itself was compromised because actors did not do things properly. In ritual, both youth and elders made claims about how they should interact beyond and within the space of the event to reverse aspects of generational inversions.

In the remainder of this article, I situate the cultural, religious, and historical background on Swaziland with regards to intergenerational identities and obligations of care-giving. This gives a baseline for assessment of discourse on contemporary social change and 'generational inversions.' Before presenting and discussing the findings, I briefly introduce the ethnographic method and discourse analysis of participant-observationderived and recorded data.

\section{Cultural, historical, and epidemiological context}

Swaziland is a small independent nation-state of approximately one million people in southeastern Africa. It is majority ethno-linguistic Swazi and organised politically under the absolute dual monarchy of King Mswati III and his mother, the Queen Mother. Like other societies regionally and historically, leaders organise subjects into gendered agegrades, and age and generation become over-determined modes of social organisation that inflect everyday practice. Swaziland is an historically patriarchal, polygynous society structured by patrilineal descent and patrilocal residency where in-marrying daughters-in-law aid and pay deference to husbands, mothers-, and elders-in-law. This has been an important affinal axis of intergenerational obligation since the colonial era. Segmentation of patrilines encourages preferential treatment by mothers' brothers of 
their sister's children, and children ideally care for their parents into old age, evincing a life course of reciprocal, intergenerational care-giving (Kuper 1950, Golomski 2013). Swazis move from being young people, bantfu labasha, into social adulthood, budzala, chronologically in their late 20 s to early 30 s and ideally in tandem with a series of customary, Christianised marital rites that join together two families through the couple. Adulthood is otherwise predicated on being a respectable provider for one's own children and older relatives, usually by undertaking work as domestic or wage labour to earn forms of wealth.

Swaziland is notable for a pernicious HIV epidemic, registering the world's highest prevalence in 2007 and holding the morbid ranking into recent years (Bicego, Nkambule, Peterson, Reed, Donnell, Ginindza et al., 2013). Nearly one of out three adult Swazi people is seropositive. Accelerated death rates formerly breached humanitarian emergency threshold status (Whiteside, Whalley \& Naysmith 2007) to the extent that several reports have also cited Swaziland as holding the world's lowest life expectancy at one time or another. This precipitous drop occurred within the span of a decade, registering more immediate perceptions and concerns about age and the life course for the wider population (Hall 2010). HIV and TB are the leading causes of death (CDC 2013, WHO 2013). Demographers and epidemiologists depict a population where younger women, younger men, and some older men are higher risk groups who are more likely to seroconvert or are HIV positive. This distribution parallels age patterns of mortality where younger people have by and large died before older people (van Schalwyk, Mndzebele, Hlophe, Calleja, Korenromp, Stoneburner et al., 2013).

In addition to biomedical treatment, many Swazis seek ritual and religious healing through Christian sources. Christian churches have been present in Swaziland since the late nineteenth century and are part and parcel of the social landscape today. Christian religion blends with some traditionalist forms in multiple ways and is evident especially at domestic life cycle rites like funerals. Increasingly, Christian churches have taken up collective efforts of psychosocial and material support in the wake of household dissolution from HIVIAIDS and collectivise their projects as faith-based organisations 
(Nyawo, Mhlobo \& Mpapane 2009, Root 2009, Root \& Whiteside 2013). Many churches provide financial support by operating rotating savings and credit groups to pay for members' funerals or engage in social projects of home visitations and spiritual healing (Golomski 2013).

\section{Methodology}

Data derives from ethnographic field research between 2008 and 2011 in Swaziland. The author conducted the research singly and resided in three different Swazi households, ranging from one to six months in duration. Daily participant-observation and conversations were recorded in field notes. Each family was self-identified Christian, and the author accompanied members to and documented funerals and marital rites of their respective families and social networks, as well as members' weekly churches' worship services. Life cycle rites took place in peoples' homes and or a church. Worship services and life cycle rites were not usually coterminous; for example, some funerals had a small additional worship service or set of speeches and testimonies, but regularly scheduled Sunday services did not include rites associated with an individual person's death. Churches ranged from newly constructed magnificent buildings for political and economic elites to poorer makeshift worship spaces in urban informal settlements and rural areas.

A range of sects were documented, including syncretic Zionist spirit churches, missionary derived Protestant churches, and globally inspired Pentecostal-charismatic groups. Zionist spirit churches predominate in Swaziland, originating in contact with early twentieth century American missionaries and blending practical and material forms of customary ritual with Christian ideals and scripture. Mission churches are similar in austere worship practices and services of European and American Christian churches, while Pentecostalists build on the mission church model but incorporate particular rites of speaking in tongues, healing via laying hands, and embellished tithing practices and ideologies. While these sects are identifiably different in character and ritual procedure, 
membership is fluid over peoples' life times and people move between sects for a variety of social, economic, and spiritual-existential reasons.

Sermons, testimonies, and ritual procedures from 55 worship services were documented in total. In addition to church services, the author attended and documented ritual procedure and speeches at 15 life cycle rites. The author and four siSwati-speaking research assistants individually and collaboratively back-translated and -transcribed 50 plus hours of recorded data. Field notes and recording transcriptions were reviewed and interpreted using discourse analysis. Discourse analysis is an assessment and interpretation that situates verbal and observational content within its multiple contexts. This elucidates micro-level, naturally occurring interactions between listeners and speakers or actors and observers and considers how these interactions indicate broader processes (Johnston 2008). Locally salient categories of personhood and facets of intergenerational relations were identified based on listeners' or observers' responses, as well the author's knowledge of and collaboration and dialogues with translator-transcriptionists about cultural context (Subedi and Rhee 2008). Situating discourse in cultural context is also ethnographic, as the categories of families and intergenerationality which interlocutors articulate are shaped by cultural themes. Indeed, per culture and religion, this article considers how families' "activities and behaviors... are shaped by the norms and practices of the religious organization" or conversely how "other kinds of intergenerational influences... shape ongoing participation in that religious culture" (Daly 2007, p. 226). Research and analytic procedures were approved before research commenced by the Brandeis University Committee for Protection of Human Subjects.

\section{Results and Discussion}

\section{'Working' on souls, selves, and society}

Ethnographic attention to the nuances of language show how the spiritual, moral, and practical animate local conceptions of action, enriching an understanding of how people 
see their actions as efficacious and judicious as related to the life course. In this case of Christian religious ritual in Swaziland, restoration of and preparation for spiritual and social life in the face of HIV was often couched in vernacular idioms of umsebenti, a noun which means both 'work' as a generalised task or wage labour and 'ritual' in the form of a life cycle rite like a funeral. 'Work' was spoken about as a primary modality to deal with and act on the sufferable conditions that afflicted youth and upended relations between generations. God's providence and cooperative moral action with others in the social world enabled humans' abilities to do this work, but it remained a difficult task.

Two initial examples of this vernacular speak to work ideated as religious ritual proper, the first from a Sunday worship service at a Jerikho Zion spirit church in an urban informal settlement. Anyone may stand to give a testimony after the congregation undertakes a 20-minute choral rite and collective march-turn-run called siguco that enables the presence of and some members' possession by holy spirits. Spiritual presence through these rites encourages members' speech. 'Work for your souls,' a woman spoke, following the siguco. 'We as mothers work to prepare our souls and for a place when the time comes to bury the flesh. We plan to save money so that when you leave the world and a family cannot pay for the funeral, there is money to provide for a service. I am an orphan with no relatives, so this work will help me and help my children if it is I who die.' Work in this sense was an active preparation for the spiritual and social wellbeing of selves and others, and in monetary savings, investment or organization of small-scale burial societies, often linked to churches, neighborhoods and families that have supplied support for funerals since the colonial era. The woman's own death would not register a generational inversion, but financial preparations for its likelihood could function to mitigate material loss and shore up her children's abilities to fulfill their respective obligations to surviving family and community members.

Another example comes from the funeral of a 30-year old man, the brother of a mission church pastor for one urban household with whom I stayed. 'We aren't afraid of where our brother is now after death because we know that he died working for the Lord,' explained a man giving testimony at the night vigil. 'We need to work for the Lord too so 
that when we die we are not afraid for our souls... You might not be able to be good husbands and wives because of poverty. Poverty has stopped us from doing our work as well. We must adhere to God who will let us go toward fulfillment.' One research assistant, a member at this man's church, helped back-translate the recording of the speech, stressing the notion of 'work' and 'destiny' as corollary metaphors for the capacities to move through the life course and as central tenets to restore intergenerational relations and youth's propriety. 'The pastor says it is important to work for your life. You need to prepare yourself and your actions whilst in this life for your salvation,' she explained generally before turning to the relationship between youth and elders. 'We should help the youth to realise their destiny. They need all the guidance they can get, which is to go to the house of the Lord.' In other words, youth get to heaven by 'working' as respectful subordinates to older church leaders.

Umsebenti, or 'work' ideated as wage labour was also evoked in religious ritual spaces and as a religiously inspired form. A final example comes from another Jerikho Zion spirit church in the town of Matsapha, marked by many private industrial sites and textile factories. Jobs at these sites present opportunities for cash to circulate across households and generations in exchange and remittances, but workers are paid poorly and face long hours, dangerous conditions, and managerial racism. Several post-siguco testimonies about 'work' at these jobs explained the ardors in terms of deference to divine authority. In one case, a man spoke doubly about the godly and managerial authorities on which peoples' work depended. 'When the day comes,' he said, 'there will be work. Down there at the factories you might be waiting at the gate for a day-job or you might have heard about an opportunity beforehand. Hallelujah! We are hired for work through our commitments and because we listen and peacefully prepare ourselves. We will do this also into eternity.' He then initiated a song much to other church members' enthusiasm: 'The work of the Lamb [of God] has no abandon.' In this instance, couching "work" as wage labour within religious ritual vernacular and action was interpretable as a way to mitigate workplace precarity, and encouraged church brethren as "workers" to acknowledge authorial prerogative-both managers and Godas a means to engender social reproduction. In this regard, studies of work and HIV 
amid poverty (George and Sprague 2011) may be enriched by paying attention to the nuances of language and culture as they inform perceptions of and motivations for work in multiple senses.

\section{Respect and intergenerational alignment}

Glimpsed in the previous examples, ethnography revealed a discourse where youth had to align and subject themselves to authority, namely elders or religious leaders under cultural notions and ritual actions of respect, deference, and obligation. In some instances, it was said that youth were partly to blame for their early deaths from HIV or otherwise due to their individual actions, but it was also widely acknowledged, especially at funerals for young people, that they died due to circumstances beyond their control. In order to re-calibrate their position in society and prevent death, youth and elders had to turn to customary modes of respect, inhlonipho. Respect is a core principle of Swazi Traditional Religion (Nyawo, Mhlobo \& Mpapane 2009) and a primary trait that adults instill in children (Zoller Booth 2004) that carries into a lifetime of social encounters with community members, chiefs, and the state (Rose 1992). Re-aligning generations was seen as a project entailing the respectful subordination of youth to elders, but was not something youth themselves found to be unbearable or abhorrent.

The first example of this dynamic comes from a Sunday school bible study session with teenagers at a rural Protestant mission church. The teacher, who was also a pastor, talked about marriage and how new young wives, bomakoti, must endure the labour expectations of their mothers- or elders-in-laws. He acknowledged that some mothersin-law were sometimes abusive, leading to fractious splits within and across households insofar that young wives might leave for personal reprieve and renounce their obligations of domestic work like feeding elders. 'You must not be like that!' he assured the students. 'Are you able to be patient when someone is standing on you like this? Are you able to endure while someone stands on you like that?' The students laughed a bit. 'I heard someone say, 'a little," he said, and continued, 'the elders are building character in you. They don't hate you; they aren't killing you. When you get older, you 
will see why they did not permit you to do some things [while you were young]. You will see that they helped you. Now we see some youth are even cursing at their parents, but I am telling you that when you are old you will say, 'I did not see what these people were doing at home, but now I thank them."

In this case, the teacher-pastor instructed youth to be deferent to their elders, even if they perceived themselves to be smothered by instruction. Youth's work requires a patience and perseverance that would pass them into adulthood, and this process unfolds over the course of one's adult life in the social relations and ritual exchanges with affines in marriage. This likewise shores up elders' authority, and reframes emotional and social relations in developmental terms of personality psychology. Youth's self-reflexive knowledge about their work for elders and the social knowledge of knowing how to relate to age-specific others would come with the eventual recognition that mutual respect with elders had been for their own maturational benefit.

An explicitly biblical example on intergenerational alignment through deference and respect comes from a sermon at a cosmopolitan Pentecostal-charismatic church in the central district. In some ways similar to the Zionists, intensive musicality in singing, swaying, and coordination with an ensemble of drums, synthesizers and guitars lead participants into glossolalia and ecstatic experience, before they turn to give testimony. Following this musical-spiritual invocation, the pastor, dressed in a fine three-piece suit, recounted Luke 8: 40-56 where a man named Jairus sought help from Jesus for his sick 12-year old daughter. Jesus made his way through a crowd to find Jairus. A bleeding woman reached out and touched his cloak, whereupon her injury was healed. The woman was singled out from the crowd and fell trembling at his feet, admitting that she touched him. Jesus responded saying, "Daughter, your faith has healed you. Go in peace." The pastor pointed out this encounter for reflection and instruction for the church congregation. 'Can you imagine you [as Jairus] are praying for your healing and miracle, but Jesus stops [to heal this other woman]? You may have your miracle delayed, [but] it's not because of a fault of your own. It's a miracle for someone else!' The pastor then focused on a standard exegesis that the healed woman had actually 
suffered from this bleeding for 12 years herself, the same number as Jairus' daughter's age.

"It was, in my eyes, fair for the woman to be healed," he continued. 'The delay of your answer and miracle does not mean anything; it is coming. This woman had to be healed because she had been sick for 12 years. The 12 year-old daughter had to be aligned with the 12 years of [the woman's] sickness. There are certain things that must be aligned before miracles are actually true. Do not rush and be judgmental and say, 'so and so hates me.' They do not hate you. It is important for a church that we have the older folks in the church to be healed, so that the younger folks may enjoy their healing as well.' As he continued, the congregation grew increasingly animated, with several people again speaking in tongues.

The pastor then explicitly aligned the characters of the bible passage with the members of the church. 'First, Jesus had to heal the [woman's] 12-year sickness. Once the older women are healed in the church, they will be able to teach the younger ones about the principles of the church. The older men in the church have to be healed first so that they teach the young men in the church. If the older men have not taught, matured, if they are not healed, they will pass on sicknesses they have to the younger generation.' This statement elicited many 'amen's' from the congregation. 'It is important that the older ones are healed,' he continued, 'and there will be an alignment of your miracles. When it comes, you will be healed. Thank God for going through it.'

In this vignette, elders were positioned above and before youth in matters of life and death, even if all humans are subjected to delayed fulfillment of healing and social or bodily transformation from sicknesses. Also like the bible study example, youth must persevere and be patient to receive spiritual healing that would enable maturation and health. Transforming bodies of elders first will help structurally align the entirety of the church congregation. Because they are repositories of elders' social and practical knowledge, youth must wait for elders' healing or be riskily susceptible to any affliction 
embodied by those elders. Thus elders must first be cleansed or healed before youth to assure non-compromised transmissions of value and wellbeing.

Finally, these findings surrounding respect and alignment are counterintuitive in that youth were the primary subjects of crisis in society's generational inversion, namely that they were more likely to predecease or be seropositive than older adults. The religious discourse of intergenerational alignment happened by privileging and in fact reproducing conventional forms of age-based hierarchy and gerontocracy, prescribing patience as deference. However, this discourse and wider reception was not marked by an intergenerational conflict. Indeed, from participant-observation and ethnography it was evident that youth directly and or performatively agreed with these sentiments about deference and respect in the space of the ritual and beyond. Through embodiment and re-interpretation of customary respect idioms in Christian religious ritual, youth are supposedly able to flourish under the aegis of elders and the church, portending a mutual alignment and reproduction of the social world broadly.

\section{Disruptions in ritual, disruptions in society}

A final cultural thematic finding was that at these worship service events and life cycle rites, statements about disruptions in social reproduction often paralleled statements about disruptions of the religious ritual procedure in situ. Mistakes of procedure were sometimes attributed to incompetence due to actors' generational identity as youth, pointing to their inability to take on roles in a space deemed the prerogative of elders. Ritual's procedural direction and primary speakers are usually older men and women, people 'who are good at that sort of work,' according to one of my key interlocutors, although youth I spoke with gladly eschewed tasks like speaking publically at funerals. In some churches, younger charismatic pastors gained credibility due to their healing or oratory abilities at worship services and rites, but were sometimes seen with suspicion for transgressing respect-laden, age-related status hierarchies (see also Werbner 2011). Overall, criticisms of ritual procedure twinned to or were enveloped in criticisms about the inversion of generational positions in society. 
The first example comes from the funeral of an interlocutor's relative named Siyabonga, chronologically in his late 20 s and unmarried. His brother shuffled to the microphone and gave the following opening remarks during the night vigil at the family's rural homestead. 'I thought that the children [siblings of the deceased] would have a representative to speak on their behalf. I was chosen, but I am but a child too! I thought they would choose another person! We thought we would have an elder to deliver a speech for us. On behalf of the children of this home, I will say sorry. The elders were looking forward to getting headscarf from their child, Siyabonga, but the Almighty took our brother. When we are together, each one of us has his or her own place, but now we don't know who will stay there in Siyabonga's place... For a mother, it is too painful, and maybe they can say, "We are sorry for another." Like other mothers in this situation, ours is feeling more pain than the rest of us. May the Lord help us in this place left by Siyabonga.'

In this case, comments about a compromised ritual preceded comments speaking to the wider social misfortunes of death and dying. People deemed social and chronological elders were present at the funeral, but without pretense the brother situated himself in distinction to the elders. His sermon cites several concerns about emotion and practices of verbal performance and care-giving work that point to the crisis of generational inversions broadly. First, the brother identifies himself as a 'child' who feared his own inability to command the prowess of speaking respectfully at a funeral. He noted his surprise in being chosen for this task by other 'children,' namely his collateral, adult siblings. Here, the intra-generational distribution and acceptance of ritual roles was problematic, for the speaker at least, who felt unqualified for this oration based on his generational identity.

Turning into social commentary, the speaker indirectly pointed out how the death of youth involved the interruption of their economic contributions to society broadly as well as to expected exchange relations with elders. Using vernacular notions of care-giving and provision, the brother noted that his elders anticipated receiving a colloquial 
'headscarf' from Siyabonga, something that when worn by older and presumably married women will make them look nice and feel loved or cared for in being clothed. Here, the headscarf is a symbol of adult children's resourcefulness, one now sadly voided. Elders ideally receive resources like food, money and the labor of in-marrying daughters and grandchildren out of deferential obligation in later life, but when youth like Siyabonga die early, this exchange is circumvented or displaced to the deceased's collaterals. Likewise, Siyabonga's death displaces his work of keeping up his own household, and his siblings are faced with the question of how to manage this property, which could be repossessed by the chiefly council or avaricious relatives if it falls into disuse for too long.

In this instance, and in many others I documented, elders claimed to be distraught over the death of young people more than they were for deaths of members of their own age cohort. Siyabonga's elderly mother was identified as the most sorrowful and pained by the death at funeral, and the brother became querulous in suggesting something to mitigate the emotional ardor. 'Maybe [funeral attendees] can say, 'we are sorry for one another' was given as a blanket condolence. Here, his words shore up the idea that parents should not mourn for their children, and, as the first vignette in this article notes, to do so could be felt as an emotional and social 'curse.' Also, his suggestion for what participants should say served to redirect a series of mutual, social actions to ameliorate sadness in situ as well as legitimate his potentially compromised or non-respectful ritual speech as a "child."

A second example comes from a morning burial service for another man in his early $30 \mathrm{~s}$ in a rural area. The vigil was well attended with some 300 attendees, many of whom were members of the deceased's relatives' churches. A brother and pastor of the deceased made the following remarks as the event began to move to the family cemetery: 'We all want to go to Heaven. We all want to rest in the Lord, be taken care of and rest, in Jesus above and inside of Heaven. Lord, heed our cries. The youth, they are just still young. These youth, the elders should guide them and go with them on the way. The youth are getting ahead of us [by dying sooner]. We all want to go over there 
[to Heaven]. Amen. I request now saints that we go over there [to the cemetery], and some go with their cars. If you see an elderly person not going in a car, take him or her. So go with your car and take some of them. While we go on foot, let us pray and sing.'

In this case, the social commentary preceded commentary on the ritual. The deceased was earlier identified as a categorical youth and in this speech was enveloped in the broader collective of young people moving along "the way" toward divine firmament. The 'way' or the 'path,' like 'work,' is a metaphor for human action and movement in the social world, namely movement through time and space in the life course with Heaven cited as a perfected endpoint. The speaker implored elders to, in tandem with youth, guide, temper, and accompany them on this path. If youth are to die before their time, survivors are uncertain as to whether or not youth achieved life benchmarks or cultivated moral sensibilities needed for heavenly incorporation. This was a mutual project directed under elders' auspices.

Here work is spoken about as moralised intergenerational interaction to assure future conditions, but the pastor likewise shored up this interaction for the event in situ. Youth must be conditioned for collective future wellbeing, but conditioning can take place more immediately by aiding elders in the present. Instructions to youth to give elders a ride to the cemetery in a car facilitated the ritual procedure and provided for elders' decreased physical capacities and compromised emotional state in the space of death like Siyabonga's mother in the previous example. It would be disrespectful and unorthodox for the elders to arrive later or behind others at the cemetery, as they are also usually front and center at the grave. Youth were mobilised in a critical, didactic manner to make sure the ritual proceeded properly.

\section{Conclusion}

It is an anthropological convention that social reproduction occurs in funerals as the dead pass into a state of ancestral or angelic personhood and the living recalibrate the social order (Jindra \& Noret 2013), but attention to the space and mode of religious 
ritual shows how recalibration across generations happens concretely in practice. This article has considered the utility and frame of ritual for identifying and describing these social dynamics in the context of disease and mortality. Indeed, in the case of Swaziland's HIV/TB/poverty syndemic, where youth predecease elders, religious ritual spaces were means to articulate locally, culturally salient ideas and practices that participants felt restored and transformed conventional dynamics of social reproduction and generational succession.

In spaces of church worship services and life cycle rites, actors collocated customary and Christianised ideals in an identifiable discourse of generational inversions and prescribed literal and metaphorical 'work' to improve society's lot. 'Work,' as preparatory laborious and ritual action, was seen as a practical and moral undertaking to reproduce relations between generations of youth and elders. Embodiment or internalisation of this work for intergenerational alignment was shored up through idioms of respect and deference. Despite the fact that youth were the subject of crisis and at risk for disease and death, elders were fore-grounded in religious ritual's salvation and healing as a precondition for youth's flourishing. Likewise, as people saw religious ritual as foundational for social reproduction, their claims about proper religious ritual procedure, involving distinct distributions of age-specific roles and obligations, enabled them to align and explain action in situ as efficacious for changing broader social processes.

The findings corroborate other studies of generations in Africa in that ritual often privileges older persons' perspectives and ideas over youth and presupposes dependency of the latter on the former (Aguilar 1998, Cliggett 2005, Svensson 2009, Quaranta 2010). Elders are conventional arbiters of socio-cultural and practical knowledge and have had greater likelihood to accrue wealth over a lifetime for potential transfers to youth. They have been strategically positioned to make powerful claims on youth's behavior in domestic and public domains where social and material resources are needed to realise processes of maturation, both social and developmental. In this Swazi case of generational inversions, the promise of succession and continuity are predicated on youth's subordination, and yet this dynamic was not totally construed as 
antagonistic or conflictual. Rather, a sense of mutuality emerged that was not wholly detrimental for youth, which points to similar findings that subordination, hierarchy and dependency can be valuable or ironically useful in Southern Africa historically and culturally (Ferguson 2013, Burchardt 2010). Indeed, global health and development policies consistently champion the rights and projects of youth in this and similar contexts, but attention to locally situated and shifting notions of intergenerational relations is critical for successful development policy objectives (Worthman 2011).

Potential study limitations surround what is conceptualized as religious ritual events as a coherent unit of (and for) description, which included both church worship services and life cycle rites. Church services draw in more explicitly religious participants. Life cycle rites are textured by Christian ideologies and objects like the bible, but involve many people who do not identify as Christian. Single attention to church services, for example, could reveal nuanced differences in attendees' intention for participation or articulation of ideas and practices that may reflect aspirations for social mobility or forging non-kin social networks within churches. Another limitation is that the majority of speakers at these events were categorically and chronologically elders, per conventions of religious ritual procedure. This inherently privileges elders' perspectives on issues of social reproduction and intergenerational relations and should not be taken as too singular. Still, this case pointed toward a sensibility of mutuality across age-groups which contributes to more holistic, cross-cultural descriptions of social life, religion and HIV in Africa, as the majority of the scholarship focuses more solely on conflict.

While data comes primarily from religious rituals of life cycle rites, a prompt for future research is to push scholars of HIVIAIDS to see ritual's analytic utility, as well as push beyond its conventional definitions. Anthropologists have shown that ritual, like religion, cannot be seen as a separate domain of social life, as this distinction often makes no sense when shared with research interlocutors and local specialists and experts. Crosscultural research on HIVIAIDS can benefit from breaking away from "life-stage ethnography" (Johnson-Hanks 2002), namely thinking beyond life cycle rites or rites of passage as singular transitions to everyday social, psychological and cultural processes 
of ritualisation as coping responses. This also shows how movement between phases of the life course and shifts in intergenerational obligations and identities do not cohere in single (ritual) events. Rather, we need an approach to the life course, intergenerational relations, and social reproduction that takes religious ritual as mediating diverse aspirations and providing a forum for encounters where different age groups reflect on and engage each other's visions of society, history, and the future.

\section{References}

Aguilar, M. (1998) The Politics of Age and Gerontocracy in Africa. Trenton, New Jersey, Africa World Press.

Alber, E., van der Geest, S. \& Reynolds White, S. (2008) Generations in Africa: Connections and Conflicts. Berlin, Lit Verlag.

Barnett, T. \& Whiteside, A. (2002) AIDS in the Twenty-First Century: Disease and Globalization. New York, Palgrave Macmillan.

Becker, F. \& Geissler, P. (2007) Searching for pathways in a landscape of death: religion and AIDS in East Africa. Journal of Religion in Africa 37(1), pp. 1-15.

Beckmann, N. (2009) AIDS and the power of God: narratives of decline and coping strategies in Zanzibar. In: Becker, F. \& Geissler, P. (eds.) AIDS and Religious Practice in Africa. Leiden, Brill.

Beckmann, N., Gusman, A., \& Shroff, C. (2014) Strings Attached: AIDS and the Rise of Transnational Connections in Africa. Oxford, Oxford University Press.

Bicego, G., Nkambule, R., Peterson, I., Reed, J., Donnell, D., Ginindza, H., Duong, Y., Patel, H., Bock, N., Phillip, N., Mao, C., Justman, J. (2013) Recent patterns in 
population-based HIV prevalence in Swaziland. PLoS One 8(10), e77101 doi:10.1371/journal.pone.0077101 (published online 15 October 2013).

Bloch, M. (2006) Deference. In: Kreinath, J., Snoek, J. \& Strausberg, M. (eds.) Theorizing Rituals (vol. 1). Leiden, Brill.

Burchardt, M. (2010) Ironies of subordination: ambivalences of gender in religious AIDS interventions in South Africa. Oxford Development Studies 38(1), pp. 63-82.

Burchardt, M., Patterson, A. \& Rasmussen, L. (2013) The politics and anti-politics of social movements: religion and HIVIAIDS in Africa. Canadian Journal of African Studies 47(2), pp. 171-185.

Carton, B. (2000) Blood from Your Children: The Colonial Origins of Generational Conflict in South Africa. Charlottesville, Virginia, University Press of Virginia.

CDC (2013) Swaziland. Global Health - Swaziland. Atlanta, Center for Disease Control and Prevention. Available at: http://www.cdc.gov/globalhealth/countries/swaziland/ [Accessed 6 June 2014].

Chazan, M. (2008) Seven "deadly" assumptions: unravelling the implications of HIVIAIDS among grandmothers in South Africa and beyond. Ageing and Society 28(7), pp. 935-958.

Christiansen, C., Utas, M. \& Vigh, H. (2006) Navigating Youth, Generating Adulthood: Social Becoming in an African Context. Uppsala, Nordiska Afrikainstitutet.

Cliggett, L. (2005) Grains from Grass: Gender, Aging and Famine in Rural Africa. Ithaca, Cornell University Press. 
Cole, J. (2010) Sex and Salvation. Chicago, University of Chicago Press.

Cole, J. \& Durham, D. (eds.) (2007) Generations and Globalization: Youth, Age, and Family in the New World Economy. Bloomington, Indiana, Indiana University Press.

Dahl, B. (2009) The "failures of culture": Christianity, kinship, and moral discourses about orphans during Botswana's AIDS crisis. Africa Today 56(1), pp. 23-43.

Daly, K. (2007) Qualitative Methods for Family Studies and Human Development. London, SAGE.

Dilger, H. (2006) The power of AIDS: kinship, mobility and the valuing of social and ritual relationships in Tanzania. African Journal of AIDS Research 5(2), pp. 109-121.

Dilger, H. \& Luig, U. (2010) Morality, Hope and Grief: Anthropologies of AIDS in Africa. New York, Berghahn.

Dilger, H., Burchardt, M. \& van Dijk, R. (2010) Introduction - The redemptive moment: HIV treatments and the production of new religious spaces. African Journal of AIDS Research 9(4), pp. 373-383.

Durham, D. \& Klaits, F. (2002) Funerals and the public space of sentiment in Botswana. Journal of Southern African Studies 28(4), pp. 777-795.

Ferguson, J. (2013) Declarations of dependence: labour, personhood, and welfare in Southern Africa. Journal of the Royal Anthropological Institute 19(2), pp. 223-242.

George, G. \& Sprague, C. (2011) HIV prevention in the world of work in sub-Saharan Africa: research and practice. African Journal of AIDS Research 10(3), pp. 291-300. 
Gibbs, A., Campbell, C., Maimane, S., Nair, Y. (2010) Mismatches between youth aspirations and participatory HIVIAIDS programmes in South Africa. African Journal of AIDS Research 9(2), pp. 153-163.

Golomski, C. (2013) Right Passages: Work, Ritual, and Regeneration in Swaziland's Age of HIVIAIDS. PhD dissertation, Department of Anthropology, Brandeis University.

Gusman, A. (2009) HIVIAIDS, Pentecostal churches, and the "Joseph Generation" in Uganda. Africa Today 56(1), pp. 67-86.

Gwebu, T. (2008) Intergenerational bargaining and wealth flows in the era of HIVIAIDS: emerging trends in Old Naledi-Gaborone, Botswana. Journal of Intergenerational Relationships 6(4), pp. 413-431.

Hall, J. (2010) The truth behind life expectancy. Swazi Observer, 10 July.

Haram, L. (2010) 'We are tired of mourning!': the economy of death and bereavement in a time of AIDS. In Dilger, H. \& Luig, U. (eds.) Morality, Hope and Grief: Anthropologies of AIDS in Africa. New York, Berghahn.

Hirsch, J., Wardlow, H., Smith, D. Jordan, Phinney, H., Parikh, S., Nathanson, C. (2009) The Secret: HIV and Marriage. Nashville, Tennessee, Vanderbilt University Press.

Honwana, A. \& deBoeck, F. (2005) Makers and Breakers: Children and Youth as Emerging Categories in Postcolonial Africa. Oxford, James Currey.

Houseman, M. (2006) Relationality. In: Kreinath, J., Snoek, J. \& Strausberg, M. (eds.) Theorizing Rituals (vol. 1). Leiden, Brill.

Humphrey, C. \& Laidlaw, J. (1994) The Archetypal Actions of Ritual. Oxford, Clarendon. 
Hunter, M. (2010) Love in a Time of AIDS: Inequality, Gender and Rights in South Africa. Bloomington, Indiana, Indiana University Press.

Ingstad, B. (2004) The value of grandchildren: changing relations between generations in Botswana. Africa 74(1), pp. 62-75.

Jindra, M. \& Noret, J. (2013) Funerals in Africa: Explorations of a Social Phenomenon. Oxford, Berghahn.

Johnson-Hanks, J. (2002) On the limits of life stage ethnography: toward a theory of vital conjunctures. American Anthropologist 104(3), pp. 865-880.

Johnston, B. (2008) Discourse Analysis. Malden, Massachusetts, Wiley-Blackwell.

Klaits, F. (2010) Death in a Church of Life. Berkeley, University of California Press.

Kuper, H. (1950) Kinship among the Swazi. In: Radcliffe-Brown, A. \& Forde, D. (eds.) African Systems of Kinship and Marriage. Oxford, Oxford University Press.

Lynch, C. \& Danely, J. (eds.) (2013) Transitions and Transformations: Cultural Perspectives on Aging and the Life Course. New York, Berghahn.

Nyawo, S., Mhlobo, P., \& Mpapane, Z. (2009) Religious Education in Context. Manzini, Swaziland, Macmillan BOLESWA.

Pfeiffer, J. (2005) Commodity fetichismo: the Holy Spirit, and the turn to Pentecostal and African Independent Churches in Central Mozambique. Culture, Medicine and Psychiatry 29(3), pp. 255-283. 
Prince, R. (2006) Popular music and Luo youth in Western Kenya: ambiguities of mobility, morality and gender in the era of AIDS. In: Christiansen, C., Utas, M. \& Vigh, H. (eds.) Navigating Youth, Generating Adulthood: Social Becoming in an African Context. Uppsala, Nordiska Afrikainstitutet.

Prince, R. (2007) Salvation and tradition: configurations of faith in a time of death. Journal of Religion in Africa 37(1), pp. 84-115.

Prince, R., Denis, P. \& van Dijk, R. (2009) Engaging Christianities: negotiating HIV/AIDS, health, and social relations in East and Southern Africa. Africa Today 56(1), pp. $\mathbf{x}-\mathbf{x v i i i . ~}$

Quaranta, I. (2010) Politics of blame: clashing moralities and the AIDS epidemic in Nso' (North-West Province, Cameroon). In: Dilger, H. \& Luig, U. (eds.) Morality, Hope and Grief: Anthropologies of AIDS in Africa. New York, Berghahn.

Reis, R. (2008) Inventing a generation: the revitalisation of 'umcwasho' in Swaziland in response to the HIVIAIDS crisis. In: Alber, E., van der Geest, S. \& Reynolds White, S. (eds.) Generations in Africa: Connections and Conflicts. Berlin, Lit Verlag.

Root, R. (2009) Religious participation and HIV-disclosure rationales among people living with HIVIAIDS in rural Swaziland. African Journal of AIDS Research 8(3), pp. 295-309.

Root, R. \& Whiteside, A. (2013) A qualitative study of community home-based care and antiretroviral adherence in Swaziland. Journal of the International AIDS Society 16(1), p. 17978. 
Rose, L. (1992) The Politics of Harmony: Land Dispute Strategies in Swaziland. New York, Cambridge University Press.

Schatz, E., Gilbert, L. \& McDonald, C. (2013) If the doctors see that they don't know how to cure the disease, they say it's AIDS: How older women in rural South Africa make sense of the HIVIAIDS epidemic. African Journal of AIDS Research 12(2), pp. 95104.

Smith, D. \& Mbakwem, B. (2010) Antiretroviral therapy and reproductive life projects: mitigating the stigma of AIDS in Nigeria. Social Science and Medicine 71(2), pp. 345352.

Subedi, B. \& Rhee, J. (2008) Negotiating collaboration across difference. Qualitative Inquiry 14(6), pp. 1070-1092.

Svensson, J. (2009) 'Muslims have instructions': HIVIAIDS, modernity and Islamic religious education in Kisumu, Kenya. In: Becker, F. \& Geissler, P. (eds.) AIDS and Religious Practice in Africa. Leiden, Brill.

Swartz, A. (2013) Legacy, legitimacy, and possibility: an exploration of community health workers across the generations in Khayelitsha, South Africa. Medical Anthropology Quarterly 27(2), pp. 139-154.

Van Schalwyk, C., Mndzebele, S., Hlophe, T., Calleja, J., Korenromp, E., Stoneburner, R., Pervilhac, C. (2013) Outcomes and impact of HIV prevention, ART and TB programs in Swaziland: early evidence from public health triangulation. PLoS One 8(7), e69437. doi:10.1371/journal.pone.0069437 (published online 26 July 2013).

Werbner, R. (2011) Holy Hustlers, Schism and Prophecy: Apostolic Reformation in Botswana. Berkeley, University of California Press. 
Wilson, M. (1977) For Men and Elders: Change in the Relations of Generations and of Men and Women among the Nyakyusa-Ngonde People, 1875-1971. London, International Africa Institute.

Whiteside, A., Whalley, A. \& Naysmith, S. (2007) Reviewing 'Emergencies' for Swaziland: Shifting the Paradigm in a New Era. Durban, Health Economics and HIV/ AIDS Research Division (HEARD) and National Emergency Response Council on HIVIAIDS (NERCHA).

WHO (2013) Second Generation, WHO Country Cooperation Strategy, 2008-2013, Swaziland. Brazzavile, Congo, WHO Regional Office for Africa.

Worthman, C. (2011) Inside-out and outside-in? global development theory, policy and youth. Ethos 39(4), pp. 432-451.

Zoller Booth, M. (2004) Culture and Education: The Social Consequences of Western Schooling in Swaziland. Lanham, Maryland, University of America Press. 